\title{
Substance use and misuse of older adults living in residential care facilities: a scoping review from a person-centred care approach
}

\author{
Lisette de Graaf ${ }^{1,2 *}$ (D), Meriam Janssen ${ }^{1}$, Tineke Roelofs ${ }^{1,2}$ and Katrien Luijkx ${ }^{1}$ \\ ${ }^{1}$ School of Social and Behavioral Sciences, Tilburg University, Tilburg, The Netherlands and ${ }^{2}$ Mijzo, \\ Waalwijk, The Netherlands \\ *Corresponding author. Email: L.I.deGraaf@tilburguniversity.edu
}

(Accepted 14 June 2021)

\begin{abstract}
Person-centred care (PCC) in residential care facilities (RCFs) is valuable but creates challenges for care professionals balancing involvement and a partnership approach for residents while considering the health and safety outcomes of all residents. This review evaluates what is known about the substance use and misuse of residents living in RCFs and what is important to study in future research to enhance PCC, especially in cases in which residents wish to choose unhealthy behaviours. A scoping review was conducted and exclusion criteria were set. The included papers were assessed on methodological quality using the Mixed Methods Appraisal Tool and the results were qualitatively analysed. The included papers consisted of studies regarding alcohol, tobacco and illicit drugs. The results showed that care professionals are involved in facilitating and regulating alcohol and tobacco. The focus of the included papers is on alcohol and tobacco. Five of the 16 papers assessed the residents' perspective. This review highlights the importance of incorporating the perspectives of residents, care professionals and the organisation to enhance PCC and enable residents to make shared and well-informed decisions in dialogue with care professionals. Future research should also assess the distinction between substance use and misuse, and how this affects implementing PCC in RCFs.
\end{abstract}

Keywords: long-term care; substance use; substance misuse; nursing home residents

\section{Introduction}

Residential care facilities (RCFs) provide complex, 24-hour, long-term care for older adults with mental and/or physical impairments. RCFs do not provide specialised care, such as addiction treatment, but they provide a home for frail older adults who are unable to take care of themselves anymore due to their mental and/or physical impairments. Residents living in RCFs are highly dependent on

(C) The Author(s), 2021. Published by Cambridge University Press. This is an Open Access article, distributed under the terms of the Creative Commons Attribution-NonCommercial-NoDerivatives licence (https://creativecommons.org/ licenses/by-nc-nd/4.0/), which permits non-commercial re-use, distribution, and reproduction in any medium, provided the original work is unaltered and is properly cited. The written permission of Cambridge University Press must be obtained for commercial re-use or in order to create a derivative work. 
their environment and their care-givers are essential, physically and psychologically (Fazio et al., 2018).

Care for older adults has been shifting from the biomedical care model towards a person-centred model of care (Koren, 2010). The predominant aim within the biomedical model was care to enhance safety, health and longevity for residents by focusing on health outcomes (White-Chu et al., 2009). The traditional model was disease-focused and impersonal (Morgan and Yoder, 2012). To incorporate the residents' personal experiences of wellbeing and dignity, this model was gradually replaced with the person-centred model of care (Edvardsson et al., 2008). The international literature provides a range of definitions of person-centred care (PCC). PCC is a holistic, biopsychosocial model of care that is responsive to the needs and values of people, and gaining an understanding of these values is a central aspect of PCC in practice (McCormack, 2004; Royal College of Psychiatrists, 2018). This model of care focuses on the wellbeing and quality of life of residents and involves residents by offering them choices and shared decision making to maximise each individual's potential (Edvardsson et al., 2008; Brownie and Nancarrow, 2013; Royal College of Psychiatrists, 2018). PCC in practice includes, for example, offering choices to residents concerning personal matters, such as determining one's own bedtime and food and beverage choices (Koren, 2010). According to Fazio et al. (2018), PCC has psychosocial benefits for residents and staff, exemplified in a decrease in agitation and improved quality of life in residents and reduced stress in staff.

When PCC is implemented regarding substance use and misuse, practical and ethical issues may arise for care professionals balancing residents' personal autonomy with the health and safety of all residents (Lester and Kohen, 2008). According to the 'dignity of risk' principle, residents should be able to have choices to fulfil their wishes, even if this results in adverse outcomes for themselves (Ibrahim and Davis, 2013). This complements the concept of PCC and means that residents should be offered informed choices and involvement in decision making regarding their substance use. In general, substance use, such as alcohol use and misuse, was reported as a potential hidden health and social problem in older adults (Iparraguirre, 2015). When residents are known with current substance misuse or have a history of misuse, implementing PCC means acting in the interest of the resident and his or her environment. This includes a consideration of the potential harm and the potential beneficial effects such as a possible increase in social participation (Kelly et al., 2018). Therefore, implementing PCC could create challenges for care professionals when the needs and values of residents result in adverse outcomes.

A previous systematic review studied the prevalence of alcohol and substance misuse among community-dwelling older adults and found that substance misuse is common but underdiagnosed (Fingerhood, 2000). Alcohol misuse was most common, but prescriptive sedative misuse was also found (Fingerhood, 2000). However, this study did not focus on older adults living in RCFs, where the dependency of the environment is eminent. In addition, the review solely studied substance misuse and did not include substance use in general. The aim of the current study is to review what is known about substance use and misuse, regarding alcohol, tobacco or non-prescribed drugs, among older adults living in RCFs. Moreover, this review aimed to identify what is important to study 
Table 1. Search terms

\begin{tabular}{|c|c|}
\hline Search terms about substance use & Search terms about residential care facilities \\
\hline 1. Substance use OR & 1. Nursing home* $\mathrm{OR}$ \\
\hline 2. Substance abuse* OR & 2. Nursing homes* $O R$ \\
\hline 3. Substance misuse OR & 3. Long term care* OR \\
\hline 4. Substance-related disorders ${ }^{\star} \mathrm{OR}$ & 4. Residential care facility $O R$ \\
\hline 5. Drug use OR & 5. Residential care facilities $\mathrm{OR}$ \\
\hline 6. Drug abuse OR & 6. Residential facility* OR \\
\hline 7. Drug misuse* OR & 7. Residential care institution OR \\
\hline 8. Alcohol OR & 8. Residential care institutions OR \\
\hline 9. Alcoholism OR & 9. Elder care OR \\
\hline 10. Tobacco* OR & 10. Elderly care OR \\
\hline 11. Smoking* OR & 11. Aged care facility OR \\
\hline 12. Cannabis* $\mathrm{OR}$ & 12. Aged care facilities OR \\
\hline 13. Marijuana use $\mathrm{OR}$ & 13. Homes for the aged ${ }^{\star} \mathrm{OR}$ \\
\hline 14. Cocaine ${ }^{\star} O R$ & 14. Assisted living facility ${ }^{*} O R$ \\
\hline 15. Heroin* OR & 15. Assisted living facilities* OR \\
\hline 16. Methadone* OR & 16. Institutional care OR \\
\hline 17. Opioid-related disorders* OR & 17. Care home OR \\
\hline 18. Ecstasy OR & 18. Care homes \\
\hline \multicolumn{2}{|l|}{ 19. MDMA OR } \\
\hline \multicolumn{2}{|l|}{ 20. Amphetamine* OR } \\
\hline \multicolumn{2}{|l|}{ 21. Methamphetamine ${ }^{\star} \mathrm{OR}$} \\
\hline \multicolumn{2}{|l|}{ 22. GHB OR } \\
\hline 23. Psilocybin* & \\
\hline
\end{tabular}

a *MeSH terms

in future research to enhance PCC in cases in which residents wish to choose unhealthy behaviours, such as smoking tobacco and drinking alcohol.

\section{Methods}

\section{Study design}

The Preferred Reporting Items for Systematic Reviews and Meta-Analyses extension for Scoping Reviews (PRISMA-ScR) checklist was used as a guideline to conduct this review (see the online supplementary material; Tricco et al., 2018). Scientific papers were gathered using six databases: PsycINFO, MEDLINE, PubMed, CINAHL, Social Services Abstracts and Sociological Abstracts, as most relevant publications are expected to be found in medical, psychological, nursing and sociologically oriented journals. 
Table 2. Exclusion criteria

1. Studies solely focusing on residential care facilities and not focusing on substance use or misuse

2. Studies conducted in a setting other than residential care facilities: short-term care settings, hospitals, retirement communities, psychiatric institutions, inpatient palliative care settings, residential treatment for substance use disorders, home care or Veteran Affairs settings

3. Studies focusing on use of medically necessary prescribed medication

4. Studies that are not empirical, e.g. systematic reviews, editorials or letters

\section{Search strategy}

The search was performed on all six databases on 26 February 2019 and updated on 6 August 2019. The search string was designed based on two themes (Table 1). The first terms were related to substance use. Substance use in this review includes all kinds of use or misuse of all substances, except for medically prescribed medication. These were excluded because the use of prescribed medication is not voluntary and misuse of prescribed medication is minimal in RCFs because care professionals are responsible for administration of this medication. The second terms relate to RCFs for older adults. In this review, studies are included when performed in facilities that provide intensive and complex inpatient 24/7 long-term care for older adults with mental and/or physical impairments. These facilities provide care to older adults representing the general population, which might include a minority of older adults with substance use disorders. This specific sub-group is not the main focus of this review. Facilities which provide specialised psychiatric or addiction care were excluded, e.g. Veteran Affairs settings were excluded from this review due to different demographic features and more prevalent mental health problems in this population. Veteran Affairs settings consist of a largely male population with a high prevalence of substance use disorders (Lemke and Schaefer, 2012).

The search was limited to peer-reviewed papers, written in English. There was no date limit set as an exclusion criterion to provide a complete and broad overview.

\section{Study selection}

The study selection was performed based on the exclusion criteria presented in Table 2. The selection process is presented in Figure 1. First, all duplicates were removed. The remaining papers were screened by title by one researcher, LG. When there was no clarity whether to include or exclude a paper, the paper was included to the abstract screening. Second, the abstracts of five papers were screened by three researchers independently (LG, MJ and TR) to increase interrater reliability in order to enhance rigour and trust. Third, of the remaining papers, the abstracts were screened by three researchers independently (LG, MJ and TR) and when there was no consensus, the paper was included in the full-text screening. Fourth, the screening of the full texts was performed by three researchers independently (LG, MJ and TR). When there was no consensus, after discussion between two researchers, the third researcher was included in the discussion. This was necessary for one paper. Finally, the snowball method was conducted to check the references of the included papers; however, this did not result in any additional papers. 


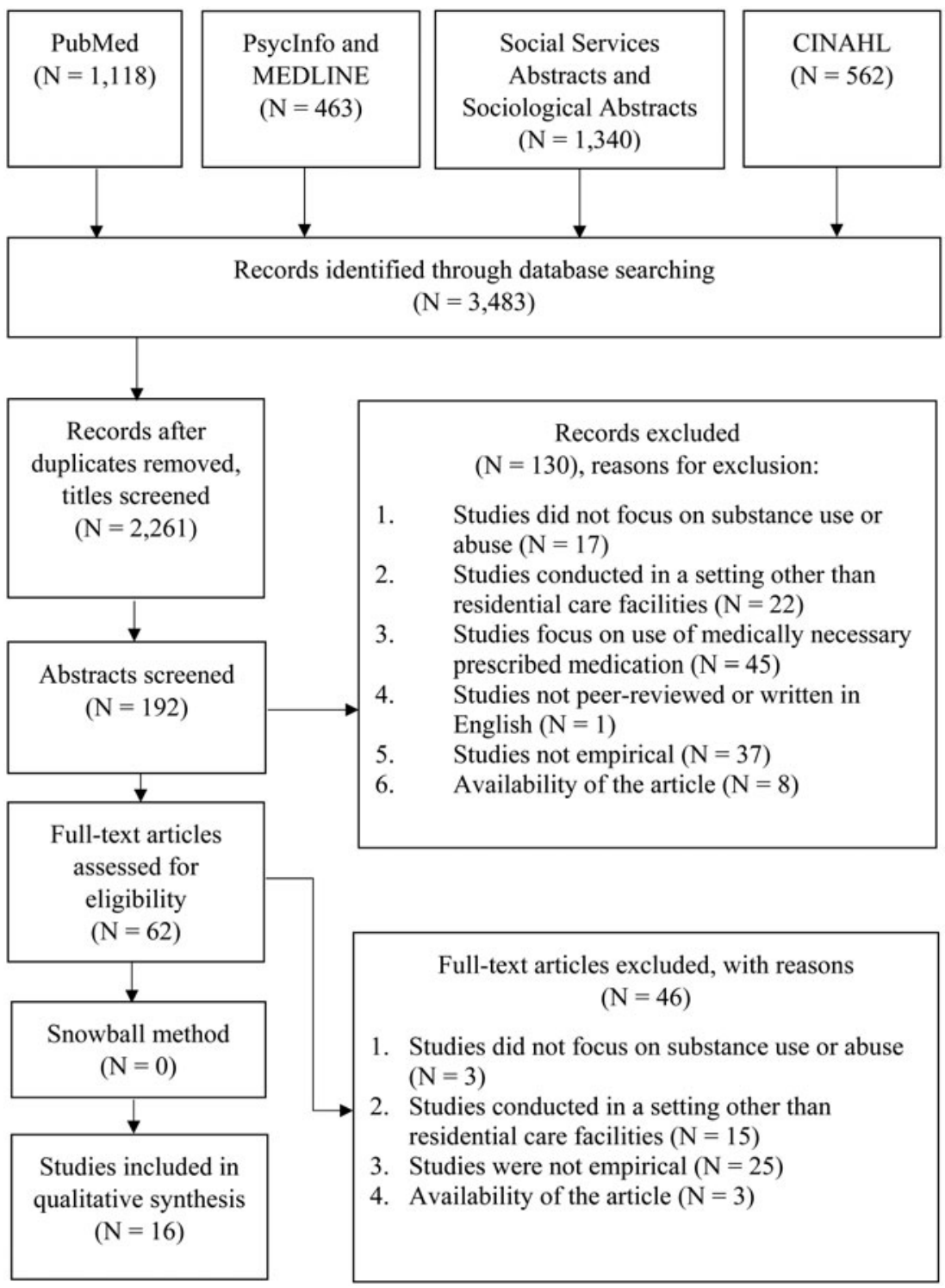

Figure 1. Flow chart of the selection process.

\section{Quality assessment}

The quality of the included papers was assessed by three researchers independently (LG, MJ and TR) using the Mixed Methods Assessment Tool (MMAT; Hong et al. 2018). The MMAT was chosen because it enables the comparison of studies with different study designs: qualitative, randomised controlled, nonrandomised, quantitative descriptive and mixed methods (Hong et al., 2018). The MMAT consists of two screening questions and five methodological quality criteria for the five different study designs. 


\section{Data extraction and analysis}

A qualitative approach for data extraction and analysis was chosen due to the broad range of study designs of the included papers. This qualitative approach consisted of a data-extraction form, which was filled in by three researchers independently (LG, MJ and TR). The data-extraction form included: title, author, year, country, aim, research question, included substances, study design, sample size, study population, setting, outcome variables, main results and limitations of each paper. Three researchers independently analysed the results qualitatively (LG, MJ and TR), resulting in a comparison of these results and a description of contrasts and similarities. Three recurrent themes were found: prevalence, policies and care professionals. These themes will be elaborated in the Results section.

\section{Results}

\section{Study characteristics}

From the 2,261 papers initially found, 16 papers were included in the data-extraction procedure, as presented in Figure 1. The study characteristics are described in Tables 3 and 4 . The included studies were conducted in five different countries. One study was conducted in two countries (Germany and Austria), the other studies were conducted in one country: the United States of America $(\mathrm{N}=$ $11)$, the United Kingdom $(\mathrm{N}=2)$, Germany $(\mathrm{N}=2)$, Austria $(\mathrm{N}=1)$, and Brazil $(\mathrm{N}=1)$. The study designs were quantitative $(\mathrm{N}=13)$, qualitative $(\mathrm{N}=1)$, and mixed methods $(\mathrm{N}=2)$, with sample sizes ranging from 19 to 1,922 participants. The drugs assessed in these studies were tobacco $(\mathrm{N}=9)$, alcohol $(\mathrm{N}=6)$ and illicit drugs $(\mathrm{N}=1)$. The studies were conducted between 1973 and 2017. The included papers regarding tobacco use were conducted between 1994 and 2010, the study regarding illicit drugs in 2015, and the studies regarding alcohol use between 1973 and 2017. Two studies, conducted in 1973 and 1975, focused mainly on the positive health outcomes of drinking alcohol for residents living in RCFs. In the period from 1994 until 2017, this focus shifted towards the prevalence and possible negative health outcomes of drinking alcohol for residents.

\section{Quality assessment}

As described in the Methods section, the methodological quality was assessed using the MMAT, with a maximum score of 5 for each study design. The quality assessment identified ten studies with scores of 3 or more and six studies with scores of 2 or less (Tables 3 and 4). These six studies have a score of less than 50 per cent of the total score. However, no studies are excluded from this dataset, due to the limited dataset. The scores are merely used to indicate the current quality of research in this field.

\section{General findings}

This section provides an overview of the overall findings and is followed by two sections elaborating the main results regarding tobacco and alcohol use. 
Table 3. Summary results for tobacco use

\begin{tabular}{|c|c|c|c|c|c|c|}
\hline Reference & Participants & Setting & Aim & Outcomes & Study design ${ }^{a}$ & $\begin{array}{l}\text { MMAT } \\
\text { score }^{\text {b }}\end{array}$ \\
\hline $\begin{array}{l}\text { Adler et al. } \\
\text { (2002) }\end{array}$ & $\begin{array}{l}\text { A } 35 \text {-item survey was } \\
\text { conducted with } 115 \\
\text { RCF social workers; } 47 \\
\text { from Georgia ( } 24.4 \% \text { of } \\
\text { participants smoked), } \\
68 \text { from Minnesota } \\
\text { (6.2\% of participants } \\
\text { smoked) }\end{array}$ & $\begin{array}{l}\text { The Georgia Nursing } \\
\text { Home Association } \\
\text { and the Minnesota } \\
\text { Nursing Home } \\
\text { Social Workers } \\
\text { Association, USA }\end{array}$ & $\begin{array}{l}\text { The aim is to } \\
\text { understand the } \\
\text { demands placed on } \\
\text { social workers with } \\
\text { regard to facilities' } \\
\text { smoking policies }\end{array}$ & $\begin{array}{l}\text { Sixteen of the facilities from Georgia and } 29 \text { of the facilities } \\
\text { in Minnesota permitted resident smoking within the } \\
\text { facility in designated areas. Seventeen of these } 45 \text { facilities } \\
\text { offered interventions to assist residents to quit smoking. } \\
\text { Twenty-one of the facilities that prohibited smoking } \\
\text { offered interventions to assist in smoking cessation. } \\
\text { Ninety-six per cent of all respondents felt residents have } \\
\text { the right to make decisions that may not be in their best } \\
\text { interest and } 95 \% \text { agreed people have the right to choose } \\
\text { to smoke. Sixty-two per cent felt that residents specifically } \\
\text { have the right to smoke. Fifty-two per cent of all social } \\
\text { workers agreed that facilities have the right to limit } \\
\text { activities of residents, such as smoking. RCF social workers } \\
\text { in smoke-free facilities were more likely to feel that } \\
\text { residents should not have the right to make their own } \\
\text { decisions regarding smoking; } 13.6 \% \text { struggle ethically with } \\
\text { the smoke-free policy. Social workers in smoking facilities } \\
\text { were more likely to report ethical concerns about the } \\
\text { personal financial cost of smoking for residents }\end{array}$ & $\begin{array}{l}\text { Quantitative descriptive } \\
\text { studies }\end{array}$ & $4 / 5$ \\
\hline $\begin{array}{l}\text { Adler et al. } \\
\text { (1997) }\end{array}$ & $\begin{array}{l}\text { A random sample of } \\
174 \text { social workers from } \\
\text { whom } 114 \\
\text { questionnaires were } \\
\text { completed and } \\
\text { returned; } 108 \text { were } \\
\text { non-smokers }\end{array}$ & $\begin{array}{l}\text { The Minnesota } \\
\text { Nursing Home } \\
\text { Social Workers and } \\
\text { the nursing homes } \\
\text { in which they work, } \\
\text { USA }\end{array}$ & $\begin{array}{l}\text { The aim is to } \\
\text { examine smoking } \\
\text { behaviour in nursing } \\
\text { home residents }\end{array}$ & $\begin{array}{l}\text { Sixty-two facilities permitted residents to smoke and } 52 \\
\text { facilities were smoke-free. Greater conflicts concerning } \\
\text { smoking arose between residents and staff in facilities } \\
\text { permitting smoking ( } 61 \% \text { ) than those that are smoke-free } \\
\text { (conflicts in } 31 \% \text { of these facilities). First, the greatest } \\
\text { conflict was a result of a lack of adequate and appropriate } \\
\text { space for smoking; second, the amount of time staff spend } \\
\text { facilitating smoking; third, issues of health effects and } \\
\text { personal safety; } 59.7 \% \text { of the social workers at } \\
\text { smoke-permitted facilities did not want the policy to } \\
\text { change as no longer being able to smoke would present } \\
\text { an additional loss for the resident. Of the social workers in } \\
\text { smoke-free facilities, } 76.9 \% \text { agreed with the policy; none of } \\
\text { these respondents smoked themselves }\end{array}$ & $\begin{array}{l}\text { Quantitative descriptive } \\
\text { studies }\end{array}$ & $3 / 5$ \\
\hline
\end{tabular}




\begin{tabular}{|c|c|c|c|c|c|c|}
\hline Reference & Participants & Setting & Aim & Outcomes & Study design ${ }^{a}$ & $\begin{array}{l}\text { MMAT } \\
\text { score }^{\text {b }}\end{array}$ \\
\hline $\begin{array}{l}\text { Barker } \\
\text { and Lewis } \\
\text { (1998) }\end{array}$ & $\begin{array}{l}\text { Interviews with } 19 \\
\text { administrators were } \\
\text { conducted, with a } \\
\text { mean age of } 45 ; 61 \% \\
\text { were female and } 42 \% \\
\text { were former smokers. } \\
\text { In addition, } \\
\text { observations of } \\
\text { resident smoking and } \\
\text { management by staff } \\
\text { and interviews with } \\
\text { residents and staff were } \\
\text { conducted in several } \\
\text { larger facilities }\end{array}$ & $\begin{array}{l}\text { Fifteen long-term } \\
\text { care facilities in San } \\
\text { Francisco, USA, with } \\
\text { a mean of } 126 \text { beds } \\
\text { per facility }\end{array}$ & $\begin{array}{l}\text { The aim is to balance } \\
\text { the rights and needs } \\
\text { of all parties } \\
\text { regarding smoking in } \\
\text { nursing homes and } \\
\text { how smoking policies } \\
\text { influence the conduct } \\
\text { of everyday life in } \\
\text { nursing homes }\end{array}$ & $\begin{array}{l}\text { Estimates of administrators of the proportion of older } \\
\text { adults in their facilities who smoked varied between } 2 \text { and } \\
10 \% \text { smoking residents and three reported none of the } \\
\text { residents smoked. No facility totally banned smoking, but } \\
\text { a variety of practices were reported to control resident } \\
\text { smoking: first, designated areas, mostly public spaces } \\
\text { instead of private spaces. Forty-seven per cent of the RCFs } \\
\text { allowed smoking in residents' rooms. Second, supervision } \\
\text { of smoking, depending on the location of smoking and the } \\
\text { mental and physical competence of the resident. Third, } \\
\text { control of smoking opportunities and smoking materials, } \\
31 \% \text { had fire-retardant materials available. Three facilities } \\
\text { (20\%) allowed residents to keep their own materials for } \\
\text { smoking; one facility reported that the smoking materials } \\
\text { of all residents were controlled by staff and } 60 \% \text { of the } \\
\text { facilities reported keeping the smoking materials of } \\
\text { residents classed as 'unsafe' smokers. Fourth, assistance } \\
\text { with smoking. Administrators addressed smoking using } \\
\text { two distinct views, first, assisting residents with smoking } \\
\text { was seen as an integral part of nursing care duties to } \\
\text { enhance quality of life and, second, assisting residents } \\
\text { with smoking was seen as a costly practice keeping staff } \\
\text { from their primary duties. Fifth, doctor's orders; five } \\
\text { facilities mentioned physician's orders. From these five, } \\
\text { four restricted smoking in specific individuals if this was } \\
\text { ordered by the physician and one permitted smoking only } \\
\text { if a physician agreed. Eighty-nine per cent of the } \\
\text { administrators saw smoking as an addiction and } 72 \% \text { as a } \\
\text { dirty habit. Seventy-eight per cent claimed that everyone, } \\
\text { including an older adult, has the right to smoke but not } \\
\text { wherever or however they pleased. The greatest } \\
\text { motivation for the development of a smoking policy by } \\
\text { administrators was a fear of fire. Smoking policies were } \\
\text { rarely discussed with residents or staff, and it was not } \\
\text { clear if care-giving staff knew exactly what the official } \\
\text { smoking policy was }\end{array}$ & Mixed methods & $2 / 5$ \\
\hline
\end{tabular}




\begin{tabular}{|c|c|c|c|c|c|c|}
\hline $\begin{array}{l}\text { Barker } \\
\text { et al. } \\
\text { (1994) }\end{array}$ & $\begin{array}{l}\text { Data were derived from } \\
\text { archives and records, } \\
\text { observations, } \\
\text { ethnography and } \\
\text { interviews. Interviews: } 5 \\
\text { administrators, } 16 \\
\text { physicians, } 31 \\
\text { registered nurses, and } \\
49 \text { other nursing staff } \\
\text { or aides, } 9 \text { ancillary } \\
\text { professional staff such } \\
\text { as social workers, } 10 \\
\text { housekeepers, } 57 \\
\text { residents }\end{array}$ & $\begin{array}{l}\text { Long-term care } \\
\text { facility in a West } \\
\text { Coast city of } \\
\text { California, USA, with } \\
\text { more than } 20 \text { wards }\end{array}$ & $\begin{array}{l}\text { The aim of this study } \\
\text { is to appreciate the } \\
\text { complexities, } \\
\text { incongruities and } \\
\text { ambiguities affecting } \\
\text { older residents } \\
\text { smoking in long-term } \\
\text { care }\end{array}$ & $\begin{array}{l}\text { Fifteen per cent of older residents were known to staff as } \\
\text { current smokers. Forty-two per cent of the } 244 \text { structured } \\
\text { observations of interactions in public places included } \\
\text { smoking by older residents. The ongoing debate of smoking } \\
\text { by residents comprises four central themes in rank order in } \\
\text { terms of importance: safety, health, autonomy and quality } \\
\text { of life. Health of smoking and non-smoking residents and } \\
\text { staff was a concern for staff. Staff could see smoking as the } \\
\text { only part over which the resident has some control and this } \\
\text { could enhance autonomy and quality of life. Policies and } \\
\text { management protocols were developed in absence of input } \\
\text { from care-giving staff or older residents. Policies were } \\
\text { defended as preserving autonomy, but the concept of } \\
\text { autonomy was simplified in these policies and were more } \\
\text { often breached than upheld. Each ward developed its own } \\
\text { management strategies to comply with overall institutional } \\
\text { policy; when a resident was labelled an 'unsafe smoker', } \\
\text { this was rarely reversed or reviewed. Nurses disliked making } \\
\text { residents use fire-retardant aprons because it diminished } \\
\text { the resident's dignity }\end{array}$ & Qualitative & $2 / 5$ \\
\hline $\begin{array}{l}\text { Carosella } \\
\text { et al. } \\
(2002)\end{array}$ & $\begin{array}{l}\text { Interviews were } \\
\text { conducted with } 95 \\
\text { residents of a long- } \\
\text { term care community } \\
\text { with a mean age of } \\
73.6 ; 38 \text { male; } 25 \\
\text { smokers and } 70 \text { non- } \\
\text { smokers }\end{array}$ & $\begin{array}{l}\text { Long-term care } \\
\text { community hospital } \\
\text { in Western New } \\
\text { York, USA: a } \\
\text { residential health } \\
\text { care facility for } \\
\text { complex or chronic } \\
\text { health conditions }\end{array}$ & $\begin{array}{l}\text { The aim is to build an } \\
\text { evidence base from } \\
\text { the residents' } \\
\text { perspective to } \\
\text { address smoking in } \\
\text { long-term care } \\
\text { facilities }\end{array}$ & $\begin{array}{l}\text { Residents classified as 'current smokers' smoked for a } \\
\text { mean of } 37.5 \text { years and a mean of } 11.6 \text { cigarettes a day. } \\
\text { Fifty-six per cent of all smokers and } 77 \% \text { of all non- } \\
\text { smokers agreed that smoking is harmful to their health; } \\
44 \% \text { of all smokers and } 24 \% \text { of all non-smokers reported } \\
\text { that quitting smoking would not improve a smoker's } \\
\text { health; } 55 \% \text { of all residents (smoking and non-smoking) } \\
\text { reported that exposure to environmental tobacco smoke } \\
\text { hurts non-smokers' health. Within this sample, smoking } \\
\text { status tended to remain as it had been prior to entering } \\
\text { the long-term care setting and } 68 \% \text { of all smokers were } \\
\text { categorised as 'precontemplators', having no intention to } \\
\text { quit within the next six months. Forty-eight per cent of all } \\
\text { smoking residents reported having received cessation } \\
\text { advice from their physician or a nurse since their } \\
\text { admission }\end{array}$ & Mixed methods & $1 / 5$ \\
\hline
\end{tabular}


Table 3. (Continued.)

\begin{tabular}{|c|c|c|c|c|c|c|}
\hline Reference & Participants & Setting & Aim & Outcomes & Study design ${ }^{a}$ & $\begin{array}{l}\text { MMAT } \\
\text { score }\end{array}$ \\
\hline $\begin{array}{l}\text { De } \\
\text { Carvalho } \\
\text { et al. } \\
(2010)\end{array}$ & $\begin{array}{l}\text { Interviews with } 116 \\
\text { smoking residents of } \\
\text { one of } 13 \text { long-term } \\
\text { care facilities with a } \\
\text { mean age of } 70 \text { ( } 81 \\
\text { men and } 35 \text { women) } \\
\text { and a minimum MMSE } \\
\text { score of } 15 \text { for illiterate, } \\
22 \text { for older adults with } \\
1-11 \text { years education } \\
\text { and } 27 \text { for more than } \\
11 \text { years of education }\end{array}$ & $\begin{array}{l}\text { One long-term care } \\
\text { facility in the } \\
\text { Federal District of } \\
\text { Brasilia, Brazil }\end{array}$ & $\begin{array}{l}\text { The aim is to } \\
\text { determine the } \\
\text { prevalence of } \\
\text { smoking among } \\
\text { older adults in a } \\
\text { long-term care } \\
\text { facility and } \\
\text { determine whether } \\
\text { the degree of } \\
\text { nicotine dependence } \\
\text { is associated with } \\
\text { socio-demographic } \\
\text { variables, affective } \\
\text { ties, motivation to } \\
\text { stop smoking and } \\
\text { depression }\end{array}$ & $\begin{array}{l}\text { Twenty-three per cent of the residents aged } 60 \text { years and } \\
\text { older were smokers, } 77.6 \% \text { showed a moderate or high } \\
\text { degree of nicotine dependence and } 57.7 \% \text { showed a low } \\
\text { motivation to quit smoking. There were significant } \\
\text { associations between the degree of nicotine dependence } \\
\text { and monthly income, level of education, affective ties, } \\
\text { motivation to quit smoking and probable depression. } \\
\text { Prevalence of smoking decreases as the age bracket } \\
\text { increases. Older adults who maintain any type of affective } \\
\text { ties seem less dependent on nicotine }\end{array}$ & $\begin{array}{l}\text { Quantitative descriptive } \\
\text { studies }\end{array}$ & $3 / 5$ \\
\hline $\begin{array}{l}\text { Watt et al. } \\
\text { (2004) }\end{array}$ & $\begin{array}{l}\text { Survey about staff } \\
\text { attitudes completed by } \\
115 \text { health-care } \\
\text { professionals who } \\
\text { worked more than half } \\
\text { time; } 93 \% \text { were women; } \\
30.4 \% \text { smokers, } 69.9 \% \\
\text { non-smokers }\end{array}$ & $\begin{array}{l}\text { Monroe Community } \\
\text { Hospital, USA, a } \\
566 \text {-bed residential } \\
\text { health-care facility } \\
\text { providing long-term } \\
\text { care to individuals } \\
\text { with complex or } \\
\text { chronic health } \\
\text { conditions }\end{array}$ & $\begin{array}{l}\text { The aim is to provide } \\
\text { an assessment of the } \\
\text { frequency of smoking } \\
\text { cessation advice and } \\
\text { beliefs influencing } \\
\text { staff to provide this } \\
\text { advice in a nursing } \\
\text { home setting }\end{array}$ & $\begin{array}{l}\text { Only } 45.6 \% \text { of the nursing staff ever advise residents to } \\
\text { quit smoking, licensed nurses ( } 54.8 \% \text { ) more often than } \\
\text { nursing assistants ( } 34.6 \%) \text {. Significant differences across } \\
\text { smoking status of staff were found: smoking staff advised } \\
\text { less frequently than non-smoking staff; } 64.5 \% \text { of the } \\
\text { nursing staff did not want to change their smoking policy } \\
\text { and } 35.5 \% \text { wanted to change the policy. The likelihood of } \\
\text { advising residents to quit smoking was the greatest when } \\
\text { resident smoking represented a safety hazard. The } \\
\text { strongest barriers to offering cessation advice for nursing } \\
\text { staff were that } 87.5 \% \text { of the staff estimated none of the } \\
\text { smoking residents were interested in quitting and an } \\
\text { institutional policy that allows smoking. Staff who } \\
\text { believed advising was more a responsibility of the } \\
\text { physician were less likely to offer advice }\end{array}$ & $\begin{array}{l}\text { Quantitative descriptive } \\
\text { studies }\end{array}$ & $5 / 5$ \\
\hline
\end{tabular}




\begin{tabular}{|c|c|c|c|c|c|c|}
\hline $\begin{array}{l}\text { Watt et al. } \\
\text { (2009) }\end{array}$ & $\begin{array}{l}\text { Forty-seven } \\
\text { administrators of } \\
\text { nursing homes were } \\
\text { asked to send the } \\
\text { policies of their facility } \\
\text { and a tool was used to } \\
\text { score these policies }\end{array}$ & $\begin{array}{l}\text { Forty-seven nursing } \\
\text { homes ranging from } \\
35 \text { to } 700 \text { beds, } \\
\text { evenly divided into } \\
\text { profit and non- } \\
\text { profit; located in } 32 \\
\text { states of the USA }\end{array}$ & $\begin{array}{l}\text { The aim is to } \\
\text { examine written } \\
\text { policies reflecting } \\
\text { nursing home } \\
\text { facilities' decisions } \\
\text { regarding resident } \\
\text { smoking }\end{array}$ & $\begin{array}{l}\text { Forty-two of the } 47 \text { facilities allowed residents to smoke } \\
\text { and five were designated as non-smoking facilities. Across } \\
\text { all facilities, there was an overall lack of } \\
\text { comprehensiveness of policies; } 78.9 \% \text { of the facilities' } \\
\text { policies did not include a statement that referred to } \\
\text { employees' rights to choose whether to assist residents } \\
\text { with smoking; } 13 \% \text { of the facilities' policies mentioned } \\
\text { that the smoking areas were well ventilated and } \\
\text { exclusively used by smokers and } 37.2 \% \text { of the policies } \\
\text { included safety precautions to protect against accidental } \\
\text { burns and fires; } 85.4 \% \text { of the policies did not address } \\
\text { tobacco education or cessation assistance and limiting } \\
\text { smoking or encouragement of smoking cessation was not } \\
\text { included in } 95.3 \%\end{array}$ & $\begin{array}{l}\text { Quantitative descriptive } \\
\text { studies }\end{array}$ & $3 / 5$ \\
\hline $\begin{array}{l}\text { Wolfsen } \\
\text { et al. } \\
\text { (2001) }\end{array}$ & $\begin{array}{l}\text { Observations of and } \\
\text { interview with } 57 \\
\text { residents; } 19 \text { smokers, } \\
38 \text { non-smokers with a } \\
\text { mean age of } 75.8 ; 46 \% \\
\text { were women; } 75 \% \text { of } \\
\text { residents were older } \\
\text { than } 65 . \text { All residents } \\
\text { have two or more } \\
\text { cognitive or functional } \\
\text { impairments }\end{array}$ & $\begin{array}{l}\text { A long-term care } \\
\text { facility with more } \\
\text { than } 500 \text { beds in a } \\
\text { major metropolitan } \\
\text { city of the USA. A } \\
\text { committee had } \\
\text { established a } \\
\text { moderately } \\
\text { restrictive smoking } \\
\text { policy }\end{array}$ & $\begin{array}{l}\text { The aim is to provide } \\
\text { a description of } \\
\text { prevalence and } \\
\text { location of smoking } \\
\text { in nursing home } \\
\text { residents and beliefs } \\
\text { of nursing home } \\
\text { residents regarding } \\
\text { smoking and health }\end{array}$ & $\begin{array}{l}\text { Fifteen per cent of all older residents smoked on a regular } \\
\text { basis, as identified by staff; } 84 \% \text { of the smoking occurred } \\
\text { outside designated smoking areas and this was rarely } \\
\text { addressed; } 74 \% \text { of the residents agreed smoking was } \\
\text { related to health outcomes; fewer smokers than non- } \\
\text { smokers related smoking to severe health consequences; } \\
\text { in general older nursing home residents did not strongly } \\
\text { believe that smoking posed a substantial risk to health }\end{array}$ & $\begin{array}{l}\text { Quantitative descriptive } \\
\text { studies }\end{array}$ & $2 / 5$ \\
\hline
\end{tabular}

Notes: MMAT: Mixed Methods Appraisal Tool. RCF: residential care facilities. USA: United States of America. 1. 2.

${ }^{\text {a }}$ Study design based on the MMAT guideline

${ }^{\text {b}}$ This score consists of the total "yes" responses for each study 
Table 4. Summary results for alcohol and illicit drug use

\begin{tabular}{|c|c|c|c|c|c|c|}
\hline Reference & Participants & Setting & Aim & Outcomes & Study design ${ }^{a}$ & $\begin{array}{l}\text { MMAT } \\
\text { score }^{\text {b }}\end{array}$ \\
\hline $\begin{array}{l}\text { Brennan } \\
(2005)\end{array}$ & $\begin{array}{l}\text { Residents } 55+: 18 \% \text {, age } 55-64 ; \\
35 \% \text {, age } 65-74 ; 25 \% \text {, age } 75-80 ; \\
22 \% \text {, age } 81+\text {. The sample: } \mathrm{N}=432 \text {. } \\
\mathrm{N}=216 \text { residents with } \\
\text { alcohol-related disorders, matched } \\
\text { case-to-case with a resident ( } \mathrm{N}= \\
216 \text { ) without alcohol-related } \\
\text { disorders. For each resident, the } \\
\text { Current Resident Questionnaire was } \\
\text { conducted with a member of staff } \\
\text { familiar with the resident }\end{array}$ & $\begin{array}{l}\text { Data from the } \\
\text { Current Resident } \\
\text { section of the } \\
1995 \text { and } 1997 \\
\text { National Nursing } \\
\text { Home Surveys, } \\
\text { USA }\end{array}$ & $\begin{array}{l}\text { The aim is to examine } \\
\text { whether AUDs } \\
\text { contribute to earlier or } \\
\text { more-intensive nursing } \\
\text { home health services }\end{array}$ & $\begin{array}{l}\text { Residents with an AUD received less } \\
\text { assistance with basic activities of daily living } \\
\text { compared to residents without an AUD. } \\
\text { Residents with an AUD used more mental } \\
\text { health and social services and have a poorer } \\
\text { quality of social relationships. The results } \\
\text { showed a significant group } \times \text { gender } \\
\text { interaction on length of stay: men with an } \\
\text { AUD had shorter lengths of stay and women } \\
\text { with an AUD had longer lengths of stay }\end{array}$ & $\begin{array}{l}\text { Non-randomised } \\
\text { studies }\end{array}$ & $5 / 5$ \\
\hline $\begin{array}{l}\text { Chien et al. } \\
\text { (1973) }\end{array}$ & $\begin{array}{l}\text { Zung self-rating scale for residents } \\
\text { and observation rating scales by } \\
\text { staff (GRS and NOSIE) in } 296 \\
\text { nursing home patients; } 64 \\
\text { participated throughout the entire } \\
\text { study; } 33 \text { men and } 31 \text { women } \\
\text { divided into three non-random } \\
\text { groups: } N=13 \text { doxepin use for } \\
\text { depression; } N=30 \text { antipsychotic } \\
\text { drug use prescribed; } N=21 \text { no } \\
\text { antipsychotic drugs needed }\end{array}$ & $\begin{array}{l}\text { Two nursing } \\
\text { homes in the } \\
\text { metropolitan area } \\
\text { of Boston, USA }\end{array}$ & $\begin{array}{l}\text { This study aims to } \\
\text { evaluate the } \\
\text { contribution of the } \\
\text { pub social milieu to } \\
\text { the benefits of } \\
\text { receiving a drink of } \\
\text { beer or wine among } \\
\text { nursing home } \\
\text { residents }\end{array}$ & $\begin{array}{l}\text { The Zung self-rating scale was used to } \\
\text { assess the level of depression in residents } \\
\text { and was not used in further analysis. Three } \\
\text { non-random groups were compared in an } \\
\text { alcoholic and non-alcoholic period and } \\
\text { showed a trend towards improvement in } \\
\text { functioning in the alcoholic period on the } \\
\text { NOSIE in the no medication group and } \\
\text { significant improvement in functioning in } \\
\text { the alcoholic period in the two treatment } \\
\text { groups. No significant differences were } \\
\text { found between the three groups. Pub } \\
\text { drinking was liked by the majority of } \\
\text { residents and facilitated more social } \\
\text { interactions but not significantly more than } \\
\text { ward drinking }\end{array}$ & $\begin{array}{l}\text { Non-randomised } \\
\text { studies }\end{array}$ & $4 / 5$ \\
\hline
\end{tabular}




\begin{tabular}{|c|c|c|c|c|c|c|}
\hline $\begin{array}{l}\text { Dreher-Weber } \\
\text { et al. (2017) }\end{array}$ & $\begin{array}{l}\text { Interviews with } 455 \text { nursing home } \\
\text { residents older than } 60 \text { : no hair } \\
\text { samples } N=111 \text {, hair samples } N= \\
344 \text {. Interviews with } 274 \\
\text { participants of nursing staff }\end{array}$ & $\begin{array}{l}\text { Thirty-three } \\
\text { nursing homes in } \\
\text { connection with } \\
\text { the inter-regional } \\
\text { project 'Alter und } \\
\text { Sucht', Germany } \\
\text { and Austria }\end{array}$ & $\begin{array}{l}\text { The aim is to describe } \\
\text { alcohol consumption } \\
\text { patterns in nursing } \\
\text { home residents, using } \\
\text { objective biomarkers } \\
\text { and evaluate the } \\
\text { validity of AUDIT-C } \\
\text { cut-offs in detecting } \\
\text { hazardous drinking in } \\
\text { older adults }\end{array}$ & $\begin{array}{l}\text { Men drank significantly more than women: } \\
11.5 \% \text { of the men and } 2.7 \% \text { of the women } \\
\text { showed chronic-excessive consumption, } \\
11.5 \% \text { of the men and } 4.7 \% \text { of the women } \\
\text { showed regular but not excessive } \\
\text { consumption and } 77 \% \text { of the men and } \\
92.6 \% \text { of the women showed low alcohol } \\
\text { consumption or abstinence; } 11.3 \% \text { of } \\
\text { nursing home residents drank above the } \\
\text { recommended limit for older adults, as } \\
\text { shown by hair analysis. The best balance of } \\
\text { the AUDIT-C, a screening instrument to } \\
\text { identify hazardous alcohol consumption, } \\
\text { between sensitivity and specificity in older } \\
\text { adults, was assessed and showed best } \\
\text { balance with a cut-off in scores of }>4 \text { for } \\
\text { men and }>2 \text { for women. Nursing staff } \\
\text { underestimated alcohol consumption in } \\
\text { residents compared to hair analysis: nursing } \\
\text { staff reported abstinence in } 31 \% \text { of the } \\
\text { residents who drank regularly but not } \\
\text { excessively and in } 40 \% \text { of the residents that } \\
\text { had chronic-excessive alcohol consumption }\end{array}$ & $\begin{array}{l}\text { Non-randomised } \\
\text { studies }\end{array}$ & $4 / 5$ \\
\hline
\end{tabular}


Table 4. (Continued.)

\begin{tabular}{|c|c|c|c|c|c|c|}
\hline Reference & Participants & Setting & Aim & Outcomes & Study design ${ }^{a}$ & $\begin{array}{l}\text { MMAT } \\
\text { score }^{b}\end{array}$ \\
\hline $\begin{array}{l}\text { Klein and Jess } \\
\text { (2002) }\end{array}$ & $\begin{array}{l}\text { Interviews with administrators or } \\
\text { staff about residents in } 111 \text { facilities } \\
\text { (facility administrators or an } \\
\text { appropriate executive staff } \\
\text { participated in the interview), } 74 \% \\
\text { of the respondents were woman }\end{array}$ & $\begin{array}{l}\text { Licensed } \\
\text { intermediate care } \\
\text { facilities and } \\
\text { licensed homes } \\
\text { for older adults in } \\
\text { a north-eastern } \\
\text { state of the USA }\end{array}$ & $\begin{array}{l}\text { The aim is to provide a } \\
\text { descriptive assessment } \\
\text { of the policies, } \\
\text { practices and } \\
\text { problems that } \\
\text { currently exist in } \\
\text { several sheltered living } \\
\text { environments for older } \\
\text { adults }\end{array}$ & $\begin{array}{l}\text { Of the responding facilities, } 57.7 \%(\mathrm{~N}=64) \\
\text { took an alcohol history of their residents at } \\
\text { admission. A variety of information was } \\
\text { asked about their alcohol history, e.g. } 28.1 \% \\
\text { of these facilities asked specifically about } \\
\text { past alcohol-related problems or about being } \\
\text { in treatment or recovery; } 55.8 \% \text { felt it was } \\
\text { appropriate or very appropriate for older } \\
\text { residents to have access to alcoholic } \\
\text { beverages; } 13.5 \% \text { of the facilities only } \\
\text { allowed residents to drink outside the } \\
\text { facility; } 26.4 \% \text { had regular cocktail hours; } \\
58.6 \% \text { required doctor's permission to } \\
\text { enable alcohol consumption; and } 36.9 \% \\
\text { reported not allowing alcohol consumption } \\
\text { at all. However, respondents stated rules } \\
\text { were not always followed. Three facilities } \\
\text { denied admission to any applicant with a } \\
\text { history of alcohol problems and } 20 \text { facilities } \\
\text { refused admission to applicants who were } \\
\text { actively engaged in problematic drinking; } \\
83.8 \% \text { reported some problems arising from } \\
\text { alcohol use, such as falls or social and } \\
\text { behavioural problems; } 86.5 \% \text { reported a } \\
\text { belief in the disease model of alcoholism; } \\
74.8 \% \text { reported no staff received any special } \\
\text { training related to alcohol }\end{array}$ & $\begin{array}{l}\text { Quantitative } \\
\text { descriptive } \\
\text { studies }\end{array}$ & $3 / 5$ \\
\hline
\end{tabular}




\begin{tabular}{|c|c|c|c|c|c|c|}
\hline $\begin{array}{l}\text { Mishara et al. } \\
\text { (1975) }\end{array}$ & $\begin{array}{l}\text { Two institutions providing care to } \\
\text { older adults: (1) 'Residence': } \\
\text { residents living here are free to } \\
\text { come and go and receive minimal } \\
\text { supervision and physical care. ( } 2 \text { ) } \\
\text { 'Nursing Home': residents with a } \\
\text { generally poor functional status and } \\
\text { greater need for supervision and } 24 \text { / } \\
7 \text { availability of nursing care. } \\
\text { Assessment methods for physical } \\
\text { health, functional and } \\
\text { socio-emotional status, previous } \\
\text { drinking history and sleep patterns } \\
\text { in } 84 \text { residents of 'Residence' ( } 19 \\
\text { men, } 65 \text { women), mean age of } 78 \text {; } \\
61 \text { residents of 'Nursing Home' ( } 22 \\
\text { men, } 39 \text { women), mean age of } 76\end{array}$ & $\begin{array}{l}\text { Two care } \\
\text { institutions for } \\
\text { older adults, } \\
\text { 'Residence' and } \\
\text { 'Nursing Home', } \\
\text { in downtown } \\
\text { Boston, USA }\end{array}$ & $\begin{array}{l}\text { The aim of this study is } \\
\text { to evaluate the } \\
\text { possible beneficial or } \\
\text { detrimental effects of } \\
\text { having alcoholic } \\
\text { beverages available }\end{array}$ & $\begin{array}{l}\text { Participants from 'Residence' functioned on } \\
\text { a more adequate level than those from } \\
\text { 'Nursing Home'. The study was conducted } \\
\text { in two phases. Phase one: group one had } \\
\text { nine weeks with alcoholic beverages } \\
\text { available and group two had nine weeks } \\
\text { with non-alcoholic beverages available. } \\
\text { Phase two: group one had nine more weeks } \\
\text { with alcoholic beverages available and } \\
\text { group two had nine weeks with alcoholic } \\
\text { beverages available. After the first phase, } \\
\text { behavioural changes were observed in } \\
\text { 'Nursing Home': increase in communication, } \\
\text { initiative, activity level and socialisation. At } \\
\text { 'Residence', a generally higher functional } \\
\text { level was shown and behaviour became } \\
\text { more varied: participants asserted their } \\
\text { individual ideas and preferences more } \\
\text { frequently and effectively. After phase two, } \\
\text { no significant negative effects were seen } \\
\text { due to the exposure of alcoholic beverages, } \\
\text { most changes were beneficial as described. } \\
\text { Positive significant findings were more } \\
\text { common in the experimental group } \\
\text { compared to the control group and for } \\
\text { drinkers opposed to non-drinkers }\end{array}$ & $\begin{array}{l}\text { Randomised } \\
\text { control trial }\end{array}$ & $3 / 5$ \\
\hline
\end{tabular}


Table 4. (Continued.)

\begin{tabular}{|c|c|c|c|c|c|c|}
\hline Reference & Participants & Setting & Aim & Outcomes & Study design ${ }^{a}$ & $\begin{array}{l}\text { MMAT } \\
\text { score }^{b}\end{array}$ \\
\hline $\begin{array}{l}\text { Weyerer et al. } \\
\text { (1999) }\end{array}$ & $\begin{array}{l}\text { A standardised assessment sheet } \\
\text { was filled in by staff about } 1,922 \\
\text { residents; } 77.1 \% \text { female; } 84.4 \% \\
\text { from the nursing care sectors, } \\
15.6 \% \text { from residential care; mean } \\
\text { age of } 81.1 \text {; all residents had been } \\
\text { diagnosed with dementia }\end{array}$ & $\begin{array}{l}\text { Twenty randomly } \\
\text { selected } \\
\text { residential and } \\
\text { nursing homes for } \\
\text { older adults in the } \\
\text { city of Mannheim, } \\
\text { Germany }\end{array}$ & $\begin{array}{l}\text { The aim is to provide a } \\
\text { description of alcohol } \\
\text { problems among } \\
\text { nursing home } \\
\text { residents; prevalence, } \\
\text { demographic and } \\
\text { clinical features, } \\
\text { association with } \\
\text { institutionalisation, or } \\
\text { a risk of falling }\end{array}$ & $\begin{array}{l}\text { Prevalence of mental and behavioural } \\
\text { disorders due to alcohol was relatively high: } \\
7.4 \% \text { of the residents were medically } \\
\text { diagnosed with these disorders upon } \\
\text { admission to the RCF. There was a higher } \\
\text { percentage with this diagnosis among male } \\
\text { residents ( } 19.1 \%) \text { compared to female } \\
\text { residents ( } 3.8 \%) \text {. According to staff, } 3.4 \% \text { of } \\
\text { the residents had abused alcohol once or } \\
\text { on several occasions in the previous four } \\
\text { weeks and men significantly more than } \\
\text { women. The prevalence of abusive alcohol } \\
\text { use receded during the course of the stay. } \\
\text { Medical diagnosis of an alcohol problem } \\
\text { was a valuable predictor of later drinking in } \\
\text { the home. The risk of falling was } \\
\text { significantly elevated among residents with } \\
\text { alcohol problems }\end{array}$ & $\begin{array}{l}\text { Quantitative } \\
\text { descriptive } \\
\text { studies }\end{array}$ & $3 / 5$ \\
\hline
\end{tabular}




\begin{tabular}{|c|c|c|c|c|}
\hline $\begin{array}{l}\text { White et al. } \\
\text { (2015) }\end{array}$ & $\begin{array}{l}\text { Interviews with } 40 \text { nursing facility } \\
\text { directors; } 25 \% \text { male, } 72.5 \% \text { female, } \\
2.5 \% \text { unspecified; with a mean age } \\
\text { of } 50 \text {, average of } 23 \text { years of work } \\
\text { experience }\end{array}$ & $\begin{array}{l}\text { Residential } \\
\text { long-term care } \\
\text { facilities licensed } \\
\text { for serving senior } \\
\text { citizens in the } \\
\text { Commonwealth } \\
\text { of Kentucky, USA }\end{array}$ & $\begin{array}{l}\text { The aim is to provide } \\
\text { an examination of } \\
\text { policies in nursing } \\
\text { homes regarding illicit } \\
\text { drug use in nursing } \\
\text { home residents; } \\
\text { whether it is perceived } \\
\text { as a current issue and } \\
\text { attitudes of } \\
\text { administrators } \\
\text { regarding illicit drug } \\
\text { use }\end{array}$ & $\begin{array}{l}\text { Five per cent of the facilities have a specialty } \\
\text { programme for residents with a substance } \\
\text { abuse problem. Some facilities have } \\
\text { services for residents who have problems } \\
\text { with alcohol abuse (15\%), illicit drug use } \\
(17.5 \%) \text { and abuse of prescription drugs } \\
(17.5 \%) \text {. Fifteen per cent have experienced } \\
\text { problems with residents obtaining alcohol, } \\
7.5 \% \text { with residents obtaining illicit drugs, } \\
17.5 \% \text { with residents improperly obtaining } \\
\text { prescription drugs. Thirty per cent } \\
\text { implemented policies or procedures } \\
\text { addressing non-medical use of drugs; } 17.5 \% \\
\text { reported to have a policy regarding use of } \\
\text { medical marijuana; } 40 \% \text { stated that during } \\
\text { admissions their facility uses assessments } \\
\text { for substance abuse, such as the CAGE and } \\
\text { AUDIT-M; } 67.5 \% \text { asked families or others } \\
\text { about possible substance use of residents at } \\
\text { admission }\end{array}$ \\
\hline
\end{tabular}

Notes: AUD: alcohol use disorder. MMAT: Mixed Methods Appraisal Tool. RCF: residential care facilities. USA: United States of America. 1. 2.

${ }^{\text {a }}$ Study design based on the MMAT guideline

bThis score consists of the total "yes" responses for each study

\section{descriptive}

studies 
First, six of the included papers show the role of care professionals in observing, facilitating or regulating the alcohol and tobacco use of residents (Barker et al., 1994; Barker and Lewis, 1998; Carosella et al., 2002; Klein and Jess, 2002; Watt et al., 2004; Dreher-Weber et al., 2017). For example, Barker and Lewis (1998) reported that care professionals decide when and how many cigarettes a resident is allowed to smoke per day. Moreover, Dreher-Weber et al. (2017) found an underestimation of the prevalence of alcohol use by nursing staff compared to the hair analysis.

Second, the populations under study varied: three studies assessed the perspective of administrators, two the perspective of social workers, six the perspective of nursing staff and five the residents' perspective. From these five studies, three studies assessed the residents' perspective through interviews with residents themselves (Carosella et al., 2002; De Carvalho et al., 2010; Dreher-Weber et al., 2017) and two added observations to their data (Mishara et al., 1975; Wolfsen et al., 2001). Two studies described their methods as assessing the residents' perspective but did not present this perspective in their results (Barker et al., 1994; Barker and Lewis, 1998). Both studies stated that they did not include the residents' perspective because the views of residents on smoking and smoking management were consistent with the staff's perspective (Barker et al., 1994; Barker and Lewis, 1998).

Third, studies assessing the use of alcohol and tobacco differed in focus and, therefore, are discussed separately in this paper. Studies regarding tobacco use balanced the right of residents to smoke with the regulation of smoking due to health and safety issues, whereas studies on alcohol focused more on the health of residents in relation to alcohol use. The study regarding illicit drug use describes issues regarding alcohol use and not further specified substance use. Therefore, this study was not assessed separately but discussed in the section regarding alcohol use.

\section{Tobacco}

Nine papers assessed tobacco use in residents living in RCFs (Barker et al., 1994; Adler et al., 1997, 2002; Barker and Lewis, 1998; Wolfsen et al., 2001; Carosella et al., 2002; Watt et al., 2004, 2009; De Carvalho et al., 2010). Results of these studies showed that policies of RCFs state that residents have the right to smoke. However, facilities often regulate smoking, with safety as the most important reason, specifically a fear of fire (Barker et al., 1994). The struggle to balance the possibilities to smoke with health and safety for all was reflected in three themes, which will be discussed here: prevalence, policies and the role of care professionals.

\section{Prevalence}

The results concerning the prevalence of tobacco use in residents show the importance of the possibilities to smoke and the low motivation of residents to quit smoking.

Four studies showed that the prevalence of smoking residents varied from 0 to 23 per cent (Barker et al., 1994; Barker and Lewis, 1998; Wolfsen et al., 2001; De Carvalho et al., 2010). In three of these studies, the prevalence in tobacco use was based on estimates made by staff, such as care professionals or administrators, and the prevalence was estimated to be between 0 and 15 per cent (Barker et al., 
1994; Barker and Lewis, 1998; Wolfsen et al., 2001). One study assessed the prevalence through information provided by nursing staff, and this was compared with information collected in interviews with the residents themselves, which resulted in an overall prevalence of 23 per cent (De Carvalho et al., 2010).

The importance of smoking and the motivation to quit in the smoking residents was also assessed (Wolfsen et al., 2001; Carosella et al. 2002; De Carvalho et al., 2010). According to Wolfsen et al. (2001), being able to smoke when and where residents wanted maintained their feeling of autonomy. Moreover, Carosella et al. (2002) found a low level of behavioural change in the smoking residents; 68 per cent of all smokers did not have the intention to quit within the next six months. De Carvalho et al. (2010) presented similar results in which 57.7 per cent of the smoking residents showed a low level of behavioural change. The limited motivation to quit is reflected in the smoking status, which tends to remain similar after admission (Carosella et al., 2002; De Carvalho et al., 2010).

\section{Policies}

The struggle to balance smoking possibilities with health and safety for all was reflected in a reported lack of overall comprehension of institutional policies (Barker et al., 1994; Barker and Lewis, 1998; Watt et al., 2009). For example, according to Barker et al. (1994), each unit within the studied facility developed their own management strategies to comply with the institutional policy, partly depending on the degree of tolerance by staff to smoking in general. These strategies varied from designated areas in which residents are allowed to smoke to not offering cigarettes to residents with dementia because nursing staff stated that these residents will forget that they smoked and, therefore, will stop asking to smoke. In addition, Barker and Lewis (1998) reported that administrators of the 15 included facilities approached smoking differently; residents' smoking was seen as an integral part of care to enhance quality of life or smoking was seen as a costly practice keeping staff from primary care. These examples show that the implementation of the institutional policies by care professionals differed per unit, which affect the possibilities of residents smoking.

\section{Care professionals}

The included studies show a role of care professionals in the regulation of smoking by residents living in RCFs (Adler et al., 1997; Barker and Lewis, 1998; Watt et al., 2004). This role could be affected by the attitudes of care professionals and, moreover, was reflected in the implementation of policies and conflicts between residents and staff (Adler et al., 1997; Barker and Lewis, 1998). Barker and Lewis (1998) found that a variety of practices were reported to control smoking, such as controlling smoking opportunities and materials; 60 per cent of the facilities kept the smoking materials of smoking residents who are classified as 'unsafe smokers' and this label was rarely reviewed or reversed.

Three studies described attitudes of administrators and care professionals regarding smoking that affected the way care professionals act towards smoking residents (Adler et al., 1997; Barker and Lewis, 1998; Watt et al., 2004). For example, Barker and Lewis (1998) found that 89 per cent of the administrators viewed smoking as an addiction and 72 per cent as a dirty habit. Administrators 
did not see assisting residents with smoking as a primary duty for care-giving staff. Of the 19 administrators who participated in their study, 21 per cent currently smoked, 42 per cent were former smokers and 37 per cent never smoked. According to Watt et al. (2004), the health beliefs of staff were not predictive of providing smoking cessation advice and, moreover, they found two experienced barriers to offering advice: an expected low level of motivation to quit in residents and institutional policies that allow residents to smoke.

Adler et al. (1997) showed that significantly greater conflicts arose regarding smoking between residents and staff in facilities permitting smoking (61\%) compared to smoke-free facilities (31\%). The most important reasons for these conflicts were a lack of adequate and appropriate space, the amount of time staff spend facilitating smoking, and issues of health and personal safety.

\section{Alcohol}

Six of the included papers studied alcohol use in residents living in RCFs (Chien et al., 1973; Mishara et al., 1975; Weyerer et al., 1999; Klein and Jess, 2002; Brennan, 2005; Dreher-Weber et al., 2017) and one paper also assessed illicit drug use (White et al., 2015). Most papers regarding alcohol use focused on the health of residents living in RCFs. The studies conducted in 1973 and 1975 mainly observed improvement in functioning, increased communication and socialisation in residents (Chien et al., 1973; Mishara et al., 1975). Studies conducted between 1994 and 2017 mostly assessed the negative effects of alcohol on mental and physical health (Weyerer et al., 1999; Klein and Jess, 2002; Brennan, 2005; White et al., 2015). For example, Brennan (2005) studied alcohol use disorders (AUDs) in residents and found that residents with an AUD required more mental health and social services. AUDs were categorised as alcohol psychosis (20\%), alcohol dependency (55\%), alcohol abuse or alcoholism (24\%), and alcoholic liver disease or other alcoholrelated disorders (1\%) according to the International Statistical Classification of Diseases and Related Health Problems 9, Clinical Modification (ICD-9-CM). In their results, residents with AUDs were studied as one group and compared with residents without AUDs. However, the studies of Dreher-Weber et al. (2017) and Weyerer et al. (1999) show a prevalence of problematic alcohol use in residents living in RCFs, 11.3 and 3.4 per cent, respectively, which means that the focus on negative health effects specifically in residents with AUDs is a small group compared to the total population of residents living in RCFs. The focus on health was also reflected in prevalence, policies and the role of care professionals.

\section{Prevalence}

As mentioned above, two studies assessed the prevalence of alcohol misuse in residents (Weyerer et al., 1999; Dreher-Weber et al., 2017). Dreher-Weber et al. (2017) identified 11.3 per cent of the residents as hazardous drinkers - those who drank above the recommended limit of less than one alcoholic unit per day (10-14 grams of alcohol per day). They also found that nursing staff underestimated the prevalence of alcohol use in residents by comparing a hair analysis with the nursing staff s estimations. Nursing staff reported abstinence in 31 per cent of the residents who drank regularly but not excessively and in 40 per cent of the residents who 
were chronic-excessive drinkers, as indicated by a hair analysis (Dreher-Weber et al., 2017). Moreover, Weyerer et al. (1999) reported that 3.4 per cent of the residents abused alcohol once or on several occasions in the previous four weeks. Alcohol consumption was estimated by staff and rated as 'none', 'moderate' or 'abusive'. Alcohol abuse was rated when residents met the criteria of alcohol abuse of the International Classification of Diseases and Related Health Problems 10 (ICD-10) and moderate alcohol use was rated when residents did not meet these criteria. Weyerer et al. (1999) also assessed the negative health outcomes in residents, specifically a health risk related to older adults. Their study reported a significantly increased risk of falling in residents with alcohol-related problems.

To assess the prevalence and the negative health outcomes of alcohol use, screening instruments were studied in two papers (White et al., 2015; DreherWeber et al., 2017). White et al. (2015) reported that 40 per cent of the included facilities used screening instruments, such as the CAGE or AUDIT-M, to assess substance misuse. Dreher-Weber et al. (2017) assessed the validity of a screening instrument, the AUDIT-C, compared to an objective biomarker (hair analysis). These screening instruments are used to identify alcohol use in residents objectively.

\section{Policies}

In contrast to studies assessing tobacco use in RCFs, only one study regarding alcohol use assessed policies towards alcohol use. The study of Klein and Jess (2002) focused on the prevention of negative health outcomes in residents and, therefore, assessed the policies to regulate alcohol use in 111 facilities. This study showed a variety of policies concerning alcohol use in residents, exemplified by providing regular cocktail hours (26.4\%), requiring doctors' permission to drink alcohol (58.6\%) or not allowing alcohol use in the facility for residents (36.9\%). Multiple policies were reported, even within the same facilities. Three out of the 111 facilities denied the admission of any applicant with a history of alcohol problems. Moreover, 83.8 per cent of the facilities reported some problems arising from alcohol use, such as falls or social and behavioural problems.

\section{Care professionals}

In one study assessing alcohol use, the role of care professionals was reflected in the management of policies (Klein and Jess, 2002). Klein and Jess (2002) described that not all staff members followed the rules or policies of their facility regarding alcohol consumption and 55.8 per cent of the 111 facilities felt it was appropriate or very appropriate for older residents to have access to alcoholic drinks. Their study also found that 86.5 per cent of the facilities believe that problematic alcohol use is a disease. It was not further elaborated as to when care professionals defined alcohol use as problematic. These results show that care professionals regulate the alcohol use in residents and demonstrate an ambiguity in the definitions of appropriate alcohol use and problematic alcohol use by care professionals.

\section{Discussion}

This scoping review was conducted to provide an overview of the published research in substance use and misuse among older adults living in RCFs and to 
identify what is important to study in future research to enhance PCC, especially in cases in which residents wish to choose unhealthy behaviours. The results of this review show that the current field of research mainly focused on alcohol and tobacco instead of other non-prescribed drugs. Moreover, the results show that care professionals have an important role in facilitating or regulating substance use and misuse. Finally, the number of studies conducted from the residents' perspective are limited.

Studies regarding tobacco use showed that the view on smoking in general changed over time. The current older population living in RCFs started smoking when smoking was highly prevalent in all age groups and before the adverse health outcomes were well-known (Elhassan and Chow, 2007; Lester and Kohen, 2008). Moreover, it was found that the motivation in residents to quit smoking is low (Carosella et al., 2002; De Carvalho et al., 2010). Most studies regarding tobacco use were conducted between 1994 and 2010, the period in which the focus on the residents' perspective increased and the focus of care in general shifted towards PCC (Fazio et al., 2018). However, when residents have a low motivation to quit smoking and limited knowledge of the adverse health outcomes, it challenges care professionals to implement PCC. The needs and values of residents in these cases may be opposite to the values of care professionals themselves which may affect the implementation of PCC in practice. Therefore, PCC in these cases requires a supportive organisational culture and knowledge of the beliefs of care professionals themselves to solve these emerging challenges. Amongst others, these aspects are prerequisites of implementing PCC in practice, according to McCormack and McCance (2006). The view on alcohol in general also evolved over time. Studies regarding alcohol use and misuse increasingly focused on the prevention of negative health outcomes. This is reflected in the studies regarding alcohol use in residents living in RCFs: studies published in 1973 and 1975 focused on the positive health outcomes of alcohol and the studies published between 1999 and 2017 focused on the negative health outcomes. This evolved view means that the current older population living in RCFs may not be aware of the adverse outcomes of substance use and misuse and, therefore, are not motivated to change. In addition, the current older population living in RCFs may experience alcohol use as beneficial, because it enhances their social participation (Iparraguirre, 2015; Kelly et al., 2018). This may increase their self-rated health and wellbeing, despite their mental and physical impairments, which enhances successful ageing. The concept of successful ageing has a variety of definitions, but was consistently related to a younger age, non-smoking, higher physical activity, better self-rated health and no cognitive impairments (Depp and Jeste, 2006). However, the frail residents living in RCFs do not meet these criteria. Wahl et al. (2016) suggested that the concept of successful ageing should be reconsidered in the presence of physical or mental impairments. With this broader definition, it could complement PCC by considering how residents living in RCFs age successfully in the light of their selfrated health and wellbeing.

Overall, care professionals are challenged to implement PCC, because it requires interpersonal and communication skills of care professionals to have a dialogue with the residents to assess their needs and values, their motivation to change, 
inform them of the currently known adverse outcomes and the consequences of their choices.

This review also showed an ambiguity for care professionals in the distinction between alcohol use and misuse in residents (Klein and Jess, 2002). Consensus of this distinction is essential to determine whether residents use or misuse alcohol. The results of this review show only a small group of residents living in RCFs who misuse alcohol (Weyerer et al., 1999; Dreher-Weber et al., 2017). Residents who misuse alcohol require a different approach with regard to PCC, exemplified in the protection of these residents by care professionals to help them overcome their misuse and, in this way, act in their best interest. Therefore, this distinction is important to know because it determines how PCC is implemented.

To enhance PCC in substance use and misuse, the role of care professionals was found to be of great importance. The findings of this review show that care professionals decide to facilitate or regulate alcohol and tobacco use (Adler et al., 1997; Barker and Lewis, 1998; Klein and Jess, 2002; Watt et al., 2004; Dreher-Weber et al., 2017), which is exemplified in the implementation or the lack of implementation of policies by care professionals (Barker and Lewis, 1998). The attitudes of care professionals towards alcohol and tobacco may affect their decision to facilitate or regulate alcohol and tobacco use in residents. In addition, not all care professionals follow the policies of their facility (Adler et al., 1997; Barker and Lewis, 1998; Klein and Jess, 2002; Watt et al., 2004). Therefore, this review shows a gap between organisational policies and the implementation of these policies by care professionals, possibly due to their own values. The values and attitudes of care professionals towards substance use and misuse may affect the dialogue with residents to assess their needs and values and inform them of the consequences of their choices. This may in turn affect implementing organisational policies regarding substance use and misuse.

In this review, only five studies assessed the perspective of residents (Mishara et al., 1975; Wolfsen et al., 2001; Carosella et al., 2002; De Carvalho et al., 2010; Dreher-Weber et al., 2017). The other studies were conducted from the perspective of administrators, social workers or nursing staff. There are a limited number of studies assessing the residents' perspective in the current field of research regarding older adults living in RCFs in general. For example, Donnelly and MacEntee (2016) reported limited knowledge on how residents living in RCFs feel about the quality of care and their own quality of life. In addition, Roelofs et al. (2015) reported that the residents' perspective was lacking in studies regarding personal matters such as intimacy and sexuality. The limited number of studies assessing the residents' perspective could be explained due to the physical and cognitive impairments in older adults living in RCFs (Fazio et al., 2018), which creates practical and ethical issues when including their perspective in scientific research. However, to enhance PCC, not only in practice but also in research, the residents' perspective is essential.

Overall, this scoping review highlights that the focus on studies regarding substance use and misuse in residents living in RCFs is consistent with the views on substances in the general population: an increased knowledge of negative health outcomes and, therefore, an increased focus on the prevention of negative health outcomes. However, the shift towards PCC in RCFs increased the focus on residents' needs and values (Royal College of Psychiatrists, 2018). This model of care involves 
residents by offering them choices and shared decision making to maximise each individual's potential (Edvardsson et al., 2008; Royal College of Psychiatrists, 2018). Therefore, challenges emerge when implementing PCC in RCFs. This review shows that to enhance PCC in RCFs regarding substance use and misuse it is important to understand the distinction between substance use and misuse, to focus on the residents' perspective, and to assess the knowledge and attitudes of residents and care professionals towards substance use and misuse. This distinction and these perspectives should be considered when implementing policies regarding substances and incorporate these policies in organisational cultures.

\section{Strengths and limitations}

A complete and broad review of the current field of research was provided, as all substances were included in this scoping review. This showed that the focus in this field of research is on alcohol and tobacco instead of other non-prescribed drugs. The methodological quality of the included studies appeared to be variable. The methodological quality of some studies was scored to be low. The studies with a lower-scored methodological quality were interpreted with more caution.

The results of this review show possible underreporting of substance use and misuse which could bias the true prevalence of substance use and misuse in the older adults living in RCFs as reported in this review. Dreher-Weber et al. (2017) found an underestimation by care professionals of the prevalence of alcohol use in residents. Other studies reported that the underreporting could be explained due to the instruments used to assess substance use and misuse, a lack of relevant drinking guidelines and increased contents of alcoholic drinks, such as a glass of wine, which may bias the actual alcohol use (Greenfield and Kerr, 2008; Lovatt et al., 2015; Britton et al., 2016).

This review focused on substance use and misuse in RCFs specifically. The nature of RCFs varied and the definitions of RCFs were ambiguous in some of the papers included in the selection process. Therefore, the inclusion process with regard to equality of the studied facilities was challenging. However, this focus on RCFs contributes to an increased awareness of the practical and ethical issues involved in substance use and misuse in residents, and this review could be part of a foundation for future research to address these issues by comparing the outcomes of this review with empirical research.

\section{Implications for future research}

Future research should incorporate the perspectives of residents, care professionals and the organisation to enhance PCC and enable residents to make shared and well-informed decisions in dialogue with care professionals. There is a need for well-considered and well-founded ethical decisions by care professionals (Bolmsjö et al., 2006), especially regarding regulating or facilitating substance use in residents living in RCFs. This may enhance providing PCC because a careful consideration of individual interests is necessary to assess the needs and values of residents and the limiting factors and possible consequences for themselves and the environment involved. Moreover, future research should assess the 
distinction between substance use and misuse and how this affects providing PCC in RCFs. The role of care professionals emphasised the dependency of residents on their care-givers to fulfil their needs and incorporate their values. This could be relevant in other care issues where the aim is to provide PCC. Therefore, future research should incorporate the challenges emerging from this review involved in implementing PCC in RCFs.

Supplementary material. The supplementary material for this article can be found at https://doi.org/10. 1017/S0144686X21001215.

Author contributions. LG conducted the literature search and selection, assessed the quality of the selected articles, extracted data and constructed the tables. MJ and TR selected the articles, assessed the quality of the selected articles and extracted data. All the authors, including KL, interpreted the findings and were involved in the drafting and revisions of the manuscript. All authors approved the publication of the article.

Ethical standards. Ethical approval was not required.

Financial support. This research received no specific grant from any funding agency, commercial or not-for-profit sectors.

Conflict of interest. The authors declare no conflicts of interest.

\section{References}

Adler G, Greeman M, Rickers S and Kuskowski M (1997) Smoking in nursing homes: conflicts and challenges. Social Work in Health Care 25, 67-81.

Adler G, Greeman M, Parker H and Kuskowski M (2002) Self-determination and residents who smoke: a dilemma for the nursing home social worker. Journal of Social Work in Long-term Care 1, 19-30.

Barker JC and Lewis DE (1998) Smoking policy in long-term care: a survey of administrators in San Francisco. Journal of Health \& Social Policy 10, 81-100.

Barker JC, Mitteness LS and Wolfsen CR (1994) Smoking and adulthood: risky business in a nursing home. Journal of Aging Studies 8, 309-326.

Bolmsjö IÅ, Edberg A-K and Sandman L (2006) Everyday ethical problems in dementia care: a teleological model. Nursing Ethics 13, 340-359.

Brennan PL (2005) Functioning and health service use among elderly nursing home residents with alcohol use disorders: findings from the National Nursing Home Survey. American Journal of Geriatric Psychiatry 13, 475-483.

Britton A, O'Neill D and Bell S (2016) Underestimating the alcohol content of a glass of wine: the implications for estimates of mortality risk. Alcohol and Alcoholism 51, 609-614.

Brownie S and Nancarrow S (2013) Effects of person-centered care on residents and staff in aged-care facilities: a systematic review. Clinical Interventions in Aging 8, 1-10.

Carosella AM, Ossip-Klein DJ, Watt CA and Podgorski C (2002) Smoking history, knowledge, and attitudes among older residents of a long-term care facility. Nicotine \& Tobacco Research 4, 161-169.

Chien C-P, Stotsky BA and Cole JO (1973) Psychiatric treatment for nursing home patients: drug, alcohol, and milieu. American Journal of Psychiatry 130, 543-548.

De Carvalho AA, Gomes L and Loureiro AML (2010) Smoking in elderly patients admitted to long-term care facilities. Jornal Brasileiro de Pneumologia 36, 339-346.

Depp CA and Jeste DV (2006) Definitions and predictors of successful aging: a comprehensive review of larger quantitative studies. American Journal of Geriatric Psychiatry 14, 6-20.

Donnelly L and MacEntee MI (2016) Care perceptions among residents of LTC facilities purporting to offer person-centred care. Canadian Journal on Aging/La Revue canadienne du vieillissement 35, 149-160.

Dreher-Weber M, Laireiter A-R, Kühberger A, Kunz I, Yegles M, Binz T, Rumpf H-J, Hoffman R, Praxenthaler V and Wurst FM (2017) Screening for hazardous drinking in nursing home residents: 
evaluating the validity of the current cutoffs of the Alcohol Use Disorder Identification TestConsumption questions by using ethyl glucuronide in hair. Alcoholism: Clinical and Experimental Research 41, 1593-1601.

Edvardsson D, Winblad B and Sandman PO (2008) Person-centred care of people with severe Alzheimer's disease: current status and ways forward. The Lancet Neurology 7, 362-367.

Elhassan A and Chow RD (2007) Smoking cessation in the elderly. Clinical Geriatrics 15, 38-45.

Fazio S, Pace D, Flinner J and Kallmyer B (2018) The fundamentals of person-centered care for individuals with dementia. The Gerontologist 58, S10-S19.

Fingerhood M (2000) Substance abuse in older people. Journal of the American Geriatrics Society 48, 985-995.

Greenfield TK and Kerr WC (2008) Alcohol measurement methodology in epidemiology: recent advances and opportunities. Addiction 103, 1082-1099.

Hong QN, Fàbregues S, Bartlett G, Boardman F, Cargo M, Dagenais P, Gagnon M-P, Griffiths F, Nicolau B, O'Cathain A, Rousseau M-C, Vedel I and Pluye P (2018) The Mixed Methods Appraisal Tool (MMAT) version 2018 for information professionals and researchers. Education for Information 34, 285-291.

Ibrahim JE and Davis MC (2013) Impediments to applying the 'dignity of risk' principle in residential aged care services. Australasian Journal on Ageing 32, 188-193.

Iparraguirre J (2015) Socioeconomic determinants of risk of harmful alcohol drinking among people aged 50 or over in England. BMJ Open 5, e007684. doi: 10.1136/bmjopen-2015-007684.

Kelly S, Olanrewaju O, Cowan A, Brayne C and Lafortune L (2018) Alcohol and older people: a systematic review of barriers, facilitators and context of drinking in older people and implications for intervention design. PLOS ONE 13, e0191189. https://doi.org/10.1371/journal.pone.0191189.

Klein WC and Jess C (2002) One last pleasure? Alcohol use among elderly people in nursing homes. Health \& Social Work 27, 193-203.

Koren MJ (2010) Person-centered care for nursing home residents: the culture-change movement. Health Affairs 29, 312-317.

Lemke S and Schaefer JA (2012) Addressing substance use disorders in VA nursing homes. Journal of Social Work Practice in the Addictions 12, 89-106.

Lester PE and Kohen I (2008) Smoking in the nursing home: a case report and literature review. Journal of the American Medical Directors Association 9, 201-203.

Lovatt M, Eadie D, Meier PS, Li J, Bauld L, Hastings G and Holmes J (2015) Lay epidemiology and the interpretation of low-risk drinking guidelines by adults in the United Kingdom. Addiction 110, 1912-1919.

McCormack B (2004) Person-centredness in gerontological nursing: an overview of the literature. Journal of Clinical Nursing 13, 31-38.

McCormack B and McCance TV (2006) Development of a framework for person-centred nursing. Journal of Advanced Nursing 56, 472-479.

Mishara BL, Kastenbaum R, Baker F and Patterson RD (1975) Alcohol effects in old age: an experimental investigation. Social Science \& Medicine (1967) 9, 535-547.

Morgan S and Yoder LH (2012) A concept analysis of person-centered care. Journal of Holistic Nursing 30, 6-15.

Roelofs TS, Luijkx KG and Embregts PJ (2015) Intimacy and sexuality of nursing home residents with dementia: a systematic review. International Psychogeriatrics 27, 367-384.

Royal College of Psychiatrists (2018) Person-centred Care: Implications for Training in Psychiatry CR215, September 2018. Available at https://www.rcpsych.ac.uk/improving-care/campaigning-for-better-mentalhealth-policy/college-reports/cr215.

Tricco AC, Lillie E, Zarin W, O'Brien KK, Colquhoun H, Levac D, Moher D, Peters MDJ, Horsley T, Weeks L, Hempel S, Akl EA, Chang C, McGowan J, Stewart L, Hartling L, Aldcroft A, Wilson MG, Garritty C, Lewin S, Godfrey CM, Macdonald MT, Langlois EV, Soares-Weiser K, Moriarty J, Clifford T, Tunçalp $\mathbf{O}$ and Straus SE (2018) PRISMA extension for scoping reviews (PRISMA-ScR): checklist and explanation. Annals of Internal Medicine 169, 467-473.

Wahl HW, Deeg D and Litwin H (2016) Successful ageing as a persistent priority in ageing research. European Journal of Ageing 13, 1-3. 
Watt CA, Carosella AM, Podgorski C and Ossip-Klein DJ (2004) Attitudes toward giving smoking cessation advice among nursing staff at a long-term residential care facility. Psychology of Addictive Behaviors 18, 56-63.

Watt CA, Lassiter JW, Boyle JR, Kulak JA and Ossip-Klein D (2009) An examination of policies addressing resident smoking in nursing homes. Journal of the American Medical Directors Association 10, 258-263.

Weyerer S, Schäufele M and Zimber A (1999) Alcohol problems among residents in old age homes in the city of Mannheim, Germany. Australian \& New Zealand Journal of Psychiatry 33, 825-830.

White-Chu EF, Graves WJ, Godfrey SM, Bonner A and Sloane P (2009) Beyond the medical model: the culture change revolution in long-term care. Journal of the American Medical Directors Association 10, 370-378.

White JB, Duncan DF, Burr Bradley D, Nicholson T, Bonaguro J and Abrahamson K (2015) Substance abuse policies in long-term care facilities: a survey with implications for education of long-term care providers. Educational Gerontology 41, 519-526.

Wolfsen CR, Barker JC and Mitteness LS (2001) Smoking and health: views of elderly nursing home residents. Journal of Gerontological Nursing 27, 6-9.

Cite this article: de Graaf L, Janssen M, Roelofs T, Luijkx K (2021). Substance use and misuse of older adults living in residential care facilities: a scoping review from a person-centred care approach. Ageing \& Society 1-27. https://doi.org/10.1017/S0144686X21001215 